\title{
Molecular characterization of VIM1 isolates of Pseudomonas aeruginosa isolated from cases of sinusitis
}

\author{
S Sasikala ${ }^{{ }^{*}}$, S Niren Andrew ${ }^{2}$, F Antony Irudhayaraj ${ }^{3}$, T Sundararaj $^{4}$ \\ From 2nd International Science Symposium on HIV and Infectious Diseases (HIV SCIENCE 2014) \\ Chennai, India. 30 January - 1 February 2014
}

\section{Background}

Acquired metallo- $\beta$-lactamases (MBLs) are emerging resistance determinants in clinically relevant Gram negative species. These enzymes confer broad spectrum $\beta$ lactam resistance, including resistance to carbapenems. Their potential for rapid and wide dissemination makes them of great concern.

\section{Methods}

This study describes the molecular characterization of 15 Pseudomonas aeruginosa strains, isolated from endoscopic pus specimens, obtained from sinusitis cases. Susceptibility testing was performed by disk diffusion assay. The MIC of ceftazidime was determined by $\mathrm{E}$ test. Ceftazidime (CDM) - EDTA combined disc test was used to screen for class B $\beta$ lactamase production. Plasmid DNA extraction was performed by alkali lysis method. The carriage of the MBL gene, blaVIM and IMP1 gene were screened by PCR. PCR products of 7 positive strains for MBL were sequenced and analysed using bioinformatics tools.

\section{Results}

Metallo-beta-lactamase was present in 9 strains. These results correlated with the presence of VIM1 gene by PCR. IMP1 gene was absent in all the 15 strains. Plasmid was present in 10 strains only. The nucleotide and deduced protein sequences were analyzed with the software available over the Internet. The nucleotide sequences reported in the study has been submitted to the Genbank and accession numbers were obtained (KF975367, KF975368, KF975369, KF975370, KF975371, KF975372, KF975373).

\footnotetext{
* Correspondence: ssasiikala@yahoo.co.in

${ }^{1}$ PG \& Research Department of Microbiology \& Biotechnology, Presidency College, Chennai, India

Full list of author information is available at the end of the article
}

A Phylogenetic tree was constructed and it consisted of 2 clades. Both the clades had evolved from the common ancestor VIM-28.

\section{Conclusion}

Direct detection of MBL genes may circumvent the problems of the phenotypic detection of carbapenemase producing microorganisms especially those exhibiting low carbapenem MICs.

\section{Authors' details}

${ }^{1}$ PG \& Research Department of Microbiology \& Biotechnology, Presidency College, Chennai, India. ${ }^{2}$ Department of Microbiology, Madras Christian College, Chennai, India. ${ }^{3}$ Department of Ear, Nose \& Throat, Rajiv Gandhi Memorial Hospital, Chennai, India. ${ }^{4}$ Jasmn Education \& Research Foundation, Chennai-600096, India.

Published: 27 May 2014

\section{doi:10.1186/1471-2334-14-S3-P62}

Cite this article as: Sasikala et al:: Molecular characterization of VIM1 isolates of Pseudomonas aeruginosa isolated from cases of sinusitis. BMC Infectious Diseases 2014 14(Suppl 3):P62.

Submit your next manuscript to BioMed Central and take full advantage of:

- Convenient online submission

- Thorough peer review

- No space constraints or color figure charges

- Immediate publication on acceptance

- Inclusion in PubMed, CAS, Scopus and Google Scholar

- Research which is freely available for redistribution 